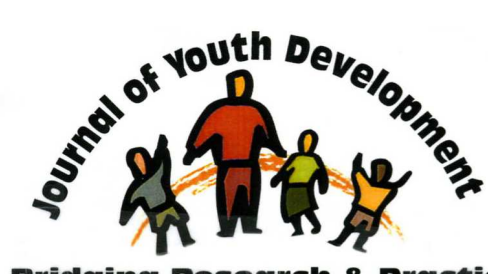

Bridging Research \& Practice

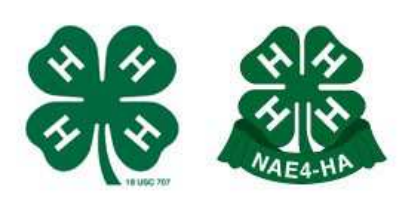

\title{
Experiential Learning: A Process for Teaching Youth Entrepreneurship
}

\author{
Karen Biers, Ph.D. \\ Entrepreneurship/Home-Based Business Extension Specialist \\ Utah State University \\ 2949 Old Main Hill \\ Logan, UT 84322-2949 \\ Phone: 435-797-2534 \\ Fax: 435-797-3845 \\ Karenb@ext.usu.edu \\ Christine Jensen, M.S. \\ Family and Consumer Sciences Extension Agent \\ Utah State University-Emery County \\ P.O. Box 847 \\ Castle Dale, UT 84513 \\ Phone: 435-381-2381 \\ Fax: 435-381-5183 \\ cjensen@ext.usu.edu \\ Ellen Serfustini, M.S. \\ Family and Consumer Sciences Extension Agent \\ Utah State University, Carbon County \\ 120 East Main \\ Price, UT 84501 \\ Phone: 435-636-3236 \\ FAX: 435-636-3210 \\ ellens@ext.usu.edu
}




\title{
JOURNAL OF YOUTH DEVELOPMENT \\ bridging research and practice

\section{Experiential Learning: A Process for Teaching Youth Entrepreneurship}

\author{
Karen Biers, Christine Jensen, and Ellen Serfustini \\ Utah State University
}

\begin{abstract}
Youth of all ages are indicating an interest in starting a business. However, few classes on business start-up and management are available. Young people who are actively engaged in learning business management concepts also develop life skills such as decision making, communicating, and learning to learn. Studies have shown that youth who are in participatory, entrepreneurship classes develop a positive attitude toward starting a business. This article addresses how the experiential learning model provides an opportunity for youth to develop entrepreneurial skills. The entrepreneurial learning model is a learning process of doing, reflecting, and then applying.
\end{abstract}

During the past two decades we've completely 're-invented' the American economy. While this dramatic change has allowed us to remain the world's economic leader, young people are simply not being prepared to participate in this rapidly changing economic landscape. Youth entrepreneurship programs are an essential part of preparing boys and girls, young men and women, to take charge of their own economic destiny.

George Gendron-Founder Inc. Magazine 


\section{Introduction}

The Bureau of Labor Statistics projects that the number of self-employed people in the United States will reach 10.2 million by 2006 . Forecasting International believes this estimate is low and projects that self-employment will reach 12 million in 2006 (Cetron \& Davies, 2005). The growth in self employment provides an opportunity for Extension Agents and volunteers to reach out to new youth audiences and provide them opportunities to have "hands-on" experience recognizing business opportunities and in starting and operating a business based on the opportunity.

Preparing youth for their future in an entrepreneurship focused world is beginning to receive attention in educational programs. Peterman and Kennedy (2003) found that high school students who had prior entrepreneurship experiences were more likely to participate in youth entrepreneurship programs; students who had negative entrepreneurship experiences were more likely to change their perceptions of entrepreneurship when they engaged in a participatory entrepreneurship class.

Entrepreneurship interest appears in young children as they set up lemonade stands, walk dogs for neighbors, or deliver newspapers. Although youth are rarely exposed to entrepreneurship as a career choice, a survey of youth 14 to 19 years of age indicates that seven out of 10 youth would like to start their own business (Walstad \& Kourilsky, 1999). Results of a study of 3,076 students indicate that $41.4 \%$ of youth $8-12$ years of age, $44.4 \%$ of youth $13-16$ years of age, and $46.7 \%$ of youth 17 years of age and older have thought about starting their own business (Consortium for Entrepreneurship Education, 2003). The percentage of youth who want to start their own business continues to increase as they age. Muske and Stanforth (2000) found that $84 \%$ of 383 college students, who were non-business majors, want to start their own business.

\section{Reasons for Starting a Business}

Youth are interested in starting a business so they can be their own boss as well as have control of their lives. However, these same youth reported that they lacked business knowledge and the skills necessary to start and operate a business (Walstad \& Kourilsky, 1999). The youth also indicated that they lacked ideas for business opportunities as well as information regarding obtaining financial capital. Youth who do not learn how to identify business opportunities and who lack business management skills, may forgo the opportunity to start a business or may start a business venture and fail.

Youth need to be aware of the opportunities and challenges that potential business owners encounter. Small business ownership continues to be a risky endeavor. Two significant factors that keep businesses from failing are entrepreneur education and business ownership by the entrepreneur's parents (Muske \& Stanforth, 2000). A "hands-on" approach to teaching youth entrepreneurship helps young people experience the concepts of business management.

This interest in youth entrepreneurship provides an opportunity for professionals working with youth. Extension business development/management programs and curriculum are available for young people of all ages. Even if youth decide to become an employee rather than a business owner, business management training will help them understand the concepts of business economics. After working with at-risk-students in a traditional school setting, Mariotti (2000) reported that the students responded to and understood math concepts more clearly when these concepts were applied to operating a business. The youth were able to apply the 
concepts to a real world situation. Mariotti reported that the students also improved reading, writing, and social skills while they learned about entrepreneurship. In addition, the students learned that they could take charge of their future.

Youth who participated in an Extension entrepreneurship program increased their knowledge about business management. Their average pre-course raw test score was 35.7 of a possible 100 and their average post-course test raw score was 70.6 (Maples and Muske, 2001). When adults were asked where they obtained information about operating their home-based business, 23.9 percent of 658 respondents indicated that they used the Cooperative Extension Service. This was the source used most frequently after friends (36.6\%) and other home-based business owners (36.8\%) (Biers, 1993).

\section{Experiential Learning}

The Association for Experiential Education (AEE) defines experiential education ". . . as a process through which a learner constructs knowledge, skill, and value from direct experiences" (Luckmann, 1996). Since its beginnings in the 1900s, 4-H has used the term "learning by doing". This term has evolved into an experiential learning model. Experiential learning is designed to be student-centered rather than teacher-centered. Student-centered learning indicates that the learner is engaged in the process through doing the activity, posing questions, experimenting, solving problems, being creative, and constructing meaning from the experience (Estes, 2004).

\section{Application of Experiential Learning to Entrepreneurship Education}

A team of Cooperative Extension personnel received funding to conduct an experience-based youth entrepreneurship pilot program in two rural counties in the Intermountain West. The program targeted youth eight to twelve years of age. The program was implemented in a two week summer day camp lasting three hours each day. To recruit participants, promotional information was distributed to the youth and their parents prior to the end of the school year. Additional promotional strategies included newspaper releases, flyers in local businesses, and local television ads.

The purpose of the program was to provide youth with situations where they could recognize business opportunities and generate ideas to create their own business. The process of starting their own business provided youth with the experience of owning and operating a business in a community/society type setting.

Camp participants created a simulated society and established a currency system. The youth determined how the currency was to be circulated so that every participant had the opportunity to earn some of the currency. The youth could use the currency to purchase resources from a community store to create a product or to start a service business. If the youth wanted to bring resources from home to make their business product, arrangements were made with parents to accept the society's currency as payment.

Participants met as a group at the end of each day to discuss the day's activities, to reflect on their experiences, and determine how to apply concepts they learned. Thus, when similar businesses opened, participants could discuss the concept of competition. Participants also compiled a resource notebook containing materials from the camp experience. On the last day 
of the camp, parents and other interested adults were invited to attend and participate in the society's business activities.

\section{Program Outcomes}

Along with business concepts, the entrepreneurship camp experience included using skills in math, language, and social interaction. It also provided an opportunity for youth to express their creative abilities.

The program evaluation results from 115 respondents indicated that they would like to open their own business during high school $(81.0 \%)$ and 83 percent indicated that they would like to start a business as an adult. Results of a camp post-evaluation showed that over three-fourths $(88.0 \%)$ of the respondents understood the basic business management skills that were covered during the program. In addition to business management skills, the respondents indicated that they learned life skills such as decision making and conflict resolution. Ninetythree percent of the young people involved reported that participation increased their public presentation abilities and 94 percent indicated that they would share the information they gained with other youth (Serfustini \& Jensen, 2005).

The results of the pilot program led to implementation in other counties. Additional Extension Agents as well as volunteer leaders received training in experiential based entrepreneurship programming. These Agents and Volunteers implemented the program in a variety of settings including:

(a) day camps

(b) after-school programs

(c) school classrooms and

(d) home-schooling programs.

\section{Discussion}

According to Kourilsky and Walstad (2000) the dominate forces for the creation of new jobs, products and services are entrepreneurship and entrepreneurial thinking. Current entrepreneurship education tends to focus on teaching business management skills and omits the core concept of entrepreneurship which includes opportunity recognition and the ability to locate resources and to create a business from the opportunity. Omission of this vital portion of entrepreneurship does not allow youth to experience the process of identifying opportunities for potential businesses. Educational futurists predicate that all education will become experienced-based by 2025 (Sanborn, Santos, Montgomery, \& Caruthers, 2005). To complement the learning experience, experiential learning involves the youth in processing what was learned and how this applies to other areas of his/her life. Experiential learning helps youth learn subject matter as well as life skills such as decision making, communicating with others, and learning to learn.

A program where the youth establish a simulated society, develop currency for the society, recognize a business opportunity, and start businesses is an excellent way to provide a foundation for youth as they increase their knowledge about entrepreneurship and business management concepts. The program is designed to illustrate the concept of scarcity and how it can lead to a business opportunity. In addition, the youth conduct market research and experience business competition. This beginning program targeting eight to twelve year old 
youth, can be followed by involving youth in the 4-H Cooperative Curriculum Systems "Be the " $\mathrm{e}$ " project. This curriculum is designed for youth of middle and high school age and provides experience-based activities. The Be the " $\mathrm{e}$ " curriculum cumulates with the youth developing a written business plan for their own business. Another opportunity for youth to experience operating a business is to participate in the Internet entrepreneurship simulation titled "Hot Shot Business" at http://www.disney.go.com/hotshot/hsb.html. This simulation is designed for youth to learn the consequences of business decisions.

\section{References}

Biers, Karen. (1993). Oklahoma home-based businesses: Representative characteristics, economic impact, educational needs. Unpublished master's thesis, Oklahoma State University, Stillwater.

Cetron, Marvin, \& Davies, Owen. (2005, May-June). Trends shaping the future: Management trends. The Futurist, 39, 47.

Consortium for Entrepreneurship Education, (2003, February). Updated findings: Youth and entrepreneurship. Retrieved February, 28, 2005, from http://www.entreed.org entre'tweens.htm

Estes, Cheryl A. (2004). Promoting student-centered learning in experiential education. [Electronic version]. Journal of Experiential Education, 2オ2), 141-160.

Kourilsky, Marilyn L., \& Walstad, William B. (2000). The E generation. Dubuque, IA: Kendall/Hunt.

Luckmann, Charles. (1996). Defining experiential education. [Electronic version]. Journal of Experiential Education, $19(1), 7$.

Mariotti, Steve. (2000). The young entrepreneur's guide to starting and running a business. New York: Three Rivers Press.

Maples, Jan, \& Muske, Glenn. (2001). Life skill/entrepreneurial education. Retrieved April 19, 2004, from http://www.fcs.okstate.edu/microbiz/economic development through microbiz.htm

Muske, Glenn, \& Stanforth, Nancy. (2000). The educational needs of small business owners: A look into the future. Journal of Extension [On-line], 38(6). Available at http://www.joe.org/joe/2000december/a4.html

Peterman, Nicole E., \& Kennedy, Jessica. (2003). Enterprise education: Influencing students' perceptions of entrepreneurship [Electronic version]. Entrepreneurship: Theory \& Practice, 28(2), 129-144.

Sanborn, Robert, Santos, Adolfo, Montgomery, Alexandra L., \& Caruthers, James B. (2005, January-February). Four scenarios for the future of education. The Futurist, 38(7), 26-30. 
Serfustini, Ellen, \& Jensen, Christine. (2006). Youth entrepreneurship: A proactive approach to helping rural economies. Journal of National Association of Family and Consumer Sciences, 2526.

Walstad, William B., \& Kourilsky, Marilyn L. (1999). Seeds of success: Entrepreneurship and youth. Dubuque, IA: Kendall/Hunt.

(C) Copyright of Journal of Youth Development $~$ Bridging Research and Practice. Content may not be copied or emailed to multiple sites or posted to a listserv without copyright holder's express written permission. Contact Editor at: patricia.dawson@oregonstate.edu for details. However, users may print, download or email articles for individual use.

ISSN 2325-4009 (Print); ISSN 2325-4017 (Online) 